\title{
Effective Causes of Suicide in Zahedan (in 2015)
}

\author{
Narges Forghani ${ }^{1} \&$ Mahmoud Bulaq ${ }^{1}$ \\ ${ }^{1}$ Department of Criminal Law and Criminology, Zahedan Branch, Islamic Azad University, Zahedan, Iran \\ Correspondence: Mahmoud Bulaq, Department of Criminal Law and Criminology, Zahedan Branch, Islamic Azad \\ University, Zahedan, Iran.
}

Received: July 4, 2016 Accepted: July 18, 2016 Online Published: July 31, 2016

doi:10.5539/jpl.v9n6p211 URL: http://dx.doi.org/10.5539/jpl.v9n6p211

\begin{abstract}
The present study aims to examine the effective causes of suicide in Zahedan city, Iran 2014-2015. In fact, suicide is a dangerous behavior to end the life, which would impose a social problem and cost a lot of harm to individuals, families and society. The main question is that what are the factors contributing to the suicide? Important assumptions include: marriage and having children reduces the suicide attempts. Education and employment could reduce the incidence of suicide attempts and suicide attempts are higher at a young age. This study makes use of fieldwork and analytical methods. The population of this research included people who committed suicide during nine months, from Azar 2014 to September 2015 and have been referred to Khatamolanbia (PBUH) hospital, Imam Ali (AS) hospital and Zahedan's forensic medicine. The findings suggest that all of 71 samples were Muslims; 36 persons were women $(50.7 \%)$ and 35 persons were men (49.3\%). There isn't any relationship between mental disorders and suicide attempts. The incidence of suicide among people 16 to 30 years old with $83.2 \%$ is much more than other age groups. Suicide attempts rates among educated people are less than under diploma with $66.2 \%$. There is no significant relationship between marital status and suicide, but suicide (67.6\%) among those without children is more than people with a family. Suicide attempts among people with higher-income levels and favorable socio-economic conditions and poor people with $15.5 \%$, is much less than middle-income and good-income with $84.5 \%$. $29.6 \%$ of those surveyed, that is 21 people, who attempted suicide had died.
\end{abstract}

Keywords: suicide, efficient causes, psychiatric disorders, abnormalities, Zahedan

\section{Introduction}

Suicide is a phenomenon as old as human history, and has been long existed in human societies and since suicide is inconsistent with the principle of survival, it has been considered reprehensible and unacceptable for all the nations. Today, along with dramatic developments in communities in various fields of science, industry and technology, we observe the rise and spread of this condemned phenomenon all over the world. Accordingly, the act of suicide has changed from individual abnormalities to a social phenomenon.

Although there are several reasons for suicidal from the psychiatric perspective including depression and psychosis that affected patients to commit suicide fantasies but the reality is that only patients do not commit suicide and that suicide has become a social problem. Suicide, like all human behavior and action means that when the person wants to commit suicide by losing their lives, it means nothing but protest against the inflexible structure.

Many attempts of those who commit suicide are to communicate to others that there is a problem. According to what mentioned above, examining the causes of suicide can pave the way for the studies which can contribute to the elimination or reduction of the effective factors. In this study, we decided to study the social problems in the city of Zahedan which is different in terms of cultural and social context from the rest of the country and to analyze the conditions and suicide risk factors. Further, the ways to prevent and deal with this behavior are also examined.

Thus those referring to the hospitals of Khatamolanbia (PBUH), Imam Ali (AS) and forensic Zahedan who attempt suicide during the nine months from January 2014 to September 2015 were studied and as expected, some interesting results were obtained in this study.

\section{The literal meaning of suicide}

Suicide in Persian Dictionary of Moein is defined as the means of killing, suicide, hard work, and too much effort (Https://www.vajehyab.com/moein) 


\section{Definition of Suicide by World Health Organization}

In 1986, for research purposes in different areas, the World Health Organization working group developed the following definition of suicide: suicide is an action with a lethal outcome in which the victim is conscious or waiting for a fatal result and commits the act to gain changes he or she demands (Palmer, 35: 2011).

\section{The History of Suicide}

The term suicide was first coined in 1642 by the doctor Sir Tom Brown in the book entitled as The Religion of a Physician. It is believed that the word "suicide" is derived from the Latin words Sui which means "self" and Caedere which means "kill". In other words, is means to kill (Palmer, 34: 2011). No period of human history can be found where suicide cases have not been recorded. This belief entered other religions such as Christianity over the centuries. According to the law of India and the influence of the Brahmin religion in ancient India, the sages who were in search of perfection and union with the eternal good frequently committed suicide during the religious festivals to get rid of all the pain and entering the world of absolute annihilation.

Suicide in addition to going to heaven causes forgiveness of the women with dead husbands. Even in 1989, 25470 women committed suicide in India due to lack of adequate dowry. In ancient times in China and Tibet people committed suicide for two reasons: one to escape from the enemy and another for access to spiritual excellence (Azar, 15: 2010). Suicide was also committed in groups. In the years after the death of Confucius five hundred of his students drowned themselves in the sea to eliminate the works of their master. So suicide was developed in China and Tibet led by Gautama, Siddhartha and Buddha. In Ancient Egypt death was considered as to escape the restrictions and problems (Azar, 15: 2010). In the late nineteenth century, Emile Durkheim, the French sociologist, and Freudian psychology seriously considered suicide (Durkheim, 221: 2009).

\section{Types of Suicide}

Durkheim in his classic study of suicide rates in France, England, and Denmark and... has divided it into four distinct groups and in each of these types provided special relationship between the individual and society based on solidarity group. He has recognized two types of correlation and four types of suicide, three types of which are structural types in which suicide rate is high and it is a result of structural changes which leads to anomaly (anomie). The core of the concept of Durkheim's discussion is cohesion. As much as Social cohesion is undermined and communication and belonging to the Group is reduced, a person finds more readiness to end his life (Sotoudeh, 222: 2010).

\section{Reasons of Suicide in Iran}

Marital problems and family disputes, unsuitable living conditions, mental disorders, falling in love and psychiatric disorders, poverty, unemployment, drug addiction, inflation and poor economic conditions. (Sotoude, 239: 1995)

\section{Sistan and Baluchestan Province}

Sistan and Baluchestan Province as the largest province of Iran is located in the South East.The province has 1210 $\mathrm{km}$ land frontier with Pakistan and Afghanistan and $370 \mathrm{~km}$ sea border on the North coast of Oman Sea and from North is limited to South Khorasan Province, from south by the Gulf of Oman, from East to Pakistan and Afghanistan and from the West to the provinces of Hormozgan and Kerman. The area of the province is 187,502 square kilometers which covers 11.5 percent of the country. According to the census of 2011 the relative density of the province is 12.5 people per square kilometer which in this respect is one of the low density provinces of the country. The figure in 2006 was 13 people per square kilometer. (Www.sbportal.ir)

\section{Methodology}

One of the characteristic that determines the credibility and value of a work is the method and instrument applied by the researcher in advance. Selecting a proper research method in addition to helping a researcher to achieve stronger and reliable results, facilitates the development of research (Hafeznia, 2008: 27).

The method used in this research included methodology, population, determining the sample size and sampling, data validity, reliability and statistical methods which the researcher is employed to analyze the research questions.

The questionnaire of the study includes two following sections: 


\section{General Questions}

\begin{tabular}{|l|l|l|l|}
\hline \multirow{5}{*}{ General questions } & index & items & Measured variable \\
\cline { 3 - 4 } & \multirow{5}{*}{ Demographic features of the respondents } & 1 & Religion \\
\cline { 3 - 4 } & 2 & Sex \\
\cline { 3 - 4 } & 3 & age \\
\cline { 3 - 4 } & 4 & education \\
\cline { 3 - 4 } & 5 & Job \\
\cline { 3 - 4 } & 6 & marital status \\
\cline { 3 - 4 } & 7 & Number of children \\
\cline { 3 - 4 } & 8 & Income level \\
\hline
\end{tabular}

Special Questions

\begin{tabular}{|l|l|l|l|}
\hline \multirow{5}{*}{ Special questions } & index & items & Measured variable \\
\cline { 3 - 4 } & \multirow{5}{*}{ Factors affecting suicide } & 1 & History of mental illness \\
\cline { 3 - 4 } & 2 & Environmental conditions \\
\cline { 3 - 4 } & 3 & Suicide \\
\cline { 3 - 4 } & 4 & Female suicide \\
\cline { 3 - 4 } & 5 & City Location \\
\cline { 3 - 4 } & 6 & Location suicide \\
\hline & 7 & The success of suicide \\
\hline
\end{tabular}

\section{Findings}

Frequency of the participants' religion

\begin{tabular}{|l|l|l|l|l|}
\hline \multicolumn{4}{|l|}{ Frequency of the participants' religion } & \multirow{2}{*}{ religion } \\
\cline { 1 - 4 } frequency & religion & valid percent & cumulative percent & \\
\hline Islam & religion & 100.0 & 100.0 & 100.0 \\
\hline
\end{tabular}

Frequency of participants' gender

\begin{tabular}{|l|l|l|l|l|}
\hline \multicolumn{5}{|l|}{ Frequency of participants' gender } \\
\hline gender & frequency & percent & Valid percent & Cumulative percent \\
\hline female & 36 & 50.7 & 50.7 & 50.7 \\
\hline male & 35 & 49.3 & 49.3 & 100.0 \\
\hline total & 71 & 100.0 & 100.0 & \\
\hline
\end{tabular}

Frequency of participants' age

\begin{tabular}{|l|l|l|l|l|}
\hline \multicolumn{5}{|l}{ Frequency of participants' age } \\
\hline age & frequency & percent & valid percent & cumulative percent \\
\hline Less than 10 & 1 & 1.4 & 1.4 & 1.4 \\
\hline $10-15$ & 2 & 2.8 & 2.8 & 4.2 \\
\hline $16-20$ & 20 & 28.2 & 28.2 & 32.4 \\
\hline $21-25$ & 20 & 28.2 & 28.2 & 60.6 \\
\hline
\end{tabular}




\begin{tabular}{|l|l|l|l|l|}
\hline $26-30$ & 19 & 26.8 & 26.8 & 87.3 \\
\hline $31-35$ & 7 & 9.9 & 9.9 & 97.2 \\
\hline $36-40$ & 1 & 1.4 & 1.4 & 98.6 \\
\hline $46-50$ & 1 & 1.4 & 1.4 & 100.0 \\
\hline total & 71 & 100.0 & 100.0 & \\
\hline
\end{tabular}

Frequency of respondents' mental history

\begin{tabular}{|l|l|l|l|l|}
\hline \multicolumn{5}{|l|}{ Frequency of respondents' mental history } \\
\hline Mental history & frequency & percent & valid percent & cumulative percent \\
\hline no & 66 & 92.9 & 92.9 & 92.9 \\
\hline yes & 5 & 7.1 & 7.1 & 100.0 \\
\hline total & 71 & 100.0 & 100.0 & \\
\hline
\end{tabular}

Frequency of respondents' education

\begin{tabular}{|l|l|l|l|l|}
\hline \multicolumn{5}{|l|}{ Frequency of respondents' education } \\
\hline Education & frequency & percent & valid percent & cumulative percent \\
\hline illiterate & 3 & 4.2 & 4.2 & 4.2 \\
\hline Primary & 13 & 18.3 & 18.3 & 22.5 \\
\hline First high school & 31 & 43.7 & 43.7 & 66.2 \\
\hline Diploma & 18 & 25.4 & 25.4 & 91.5 \\
\hline Associate Degree & 4 & 5.6 & 5.6 & 97.2 \\
\hline Bachelor & 1 & 1.4 & 1.4 & 98.6 \\
\hline MA & 1 & 1.4 & 1.4 & 100.0 \\
\hline total & 71 & 100.0 & 100.0 & \\
\hline
\end{tabular}

Frequency of respondents' marital status

\begin{tabular}{|l|l|l|l|l|}
\hline \multicolumn{5}{|l|}{ Frequency of respondents' marital status } \\
\hline marital status & frequency & percent & valid percent & cumulative percent \\
\hline single & 33 & 46.5 & 46.5 & 46.5 \\
\hline married & 38 & 53.5 & 53.5 & 100.0 \\
\hline total & 71 & 100.0 & 100.0 & \\
\hline
\end{tabular}

Frequency of respondents' children

\begin{tabular}{|l|l|l|l|l|}
\hline \multicolumn{5}{|l|}{ Frequency of respondents' children } \\
\hline children & frequency & percent & valid percent & cumulative percent \\
\hline female & 15 & 21.1 & 21.1 & 21.1 \\
\hline male & 6 & 8.5 & 8.5 & 29.6 \\
\hline No child & 48 & 67.6 & 67.6 & 97.2 \\
\hline both & 2 & 2.8 & 2.8 & 100.0 \\
\hline total & 71 & 100.0 & 100.0 & \\
\hline
\end{tabular}


Frequency of respondents' income

\begin{tabular}{|l|l|l|l|l|}
\hline \multicolumn{5}{|l|}{ Frequency of respondents' income } \\
\hline Income level & frequency & percent & valid percent & cumulative percent \\
\hline Weak & 10 & 14.1 & 14.1 & 14.1 \\
\hline Average & 35 & 49.3 & 49.3 & 63.4 \\
\hline Good & 25 & 35.2 & 35.2 & 98.6 \\
\hline Excellent & 1 & 1.4 & 1.4 & 100.0 \\
\hline total & 71 & 100.0 & 100.0 & \\
\hline
\end{tabular}

Frequency of success in suicide

\begin{tabular}{|l|l|l|l|l|}
\hline \multicolumn{5}{|l|}{ Frequency of success in suicide } \\
\hline Success in suicide & frequency & percent & valid percent & cumulative percent \\
\hline yes & 21 & 29.6 & 29.6 & 29.6 \\
\hline no & 50 & 70.4 & 70.4 & 100.0 \\
\hline total & 71 & 100.0 & 100.0 & \\
\hline
\end{tabular}

Frequency of respondents' environmental conditions

\begin{tabular}{|l|l|l|l|l|}
\hline \multicolumn{5}{|l|}{ Frequency of respondents' environmental conditions } \\
\hline Environmental conditions & frequency & percent & valid percent & cumulative percent \\
\hline Physical violence & 14 & 11.9 & 11.9 & 11.9 \\
\hline Parental conflicts & 6 & 5.1 & 5.1 & 16.9 \\
\hline Arguing with children & 1 & 8. & 8. & 17.8 \\
\hline Forced marriage & 5 & 4.2 & 4.2 & 22.0 \\
\hline Physical violence wife & 11 & 9.3 & 9.3 & 31.4 \\
\hline Argument with wife & 8 & 6.8 & 6.8 & 38.1 \\
\hline Life crisis events & 15 & 12.7 & 12.7 & 50.8 \\
\hline Unemployment & 3 & 2.5 & 2.5 & 53.4 \\
\hline Despair & 2 & 1.7 & 1.7 & 55.1 \\
\hline Family prejudices & 11 & 9.3 & 9.3 & 64.4 \\
\hline Drug addiction & 17 & 14.4 & 14.4 & 78.8 \\
\hline Divorce wife & 1 & 8. & 8. & 79.7 \\
\hline Psychotropic drugs & 5 & 4.2 & 4.2 & 83.9 \\
\hline Drug addiction & 1 & 8. & 8. & 84.7 \\
\hline Suffering and health problems & 1 & 8. & 8. & 85.6 \\
\hline Bankruptcy & 3 & 2.5 & 2.5 & 88.1 \\
\hline Marital discord & 7 & 5.9 & 5.9 & 94.1 \\
\hline Mental illness & 2 & 1.7 & 1.7 & 95.8 \\
\hline Anger & 1 & 8. & 8. & 96.6 \\
\hline Infertility & 4 & 3.4 & 3.4 & 100.0 \\
\hline total & 118 & 100.0 & 100.0 & \\
\hline & & & & \\
\hline
\end{tabular}


Frequency of respondents' suicide type

\begin{tabular}{|l|l|l|l|l|}
\hline \multicolumn{5}{|l|}{ Frequency of respondents' suicide type } \\
\hline Type & frequency & percent & valid percent & cumulative percent \\
\hline medicine & 34 & 47.9 & 47.9 & 47.9 \\
\hline Self-mutilation & 3 & 4.2 & 4.2 & 52.1 \\
\hline gun & 4 & 5.6 & 5.6 & 57.7 \\
\hline hanging & 3 & 4.2 & 4.2 & 62.0 \\
\hline poison & 1 & 1.4 & 1.4 & 63.4 \\
\hline Self-Immolation & 24 & 33.8 & 33.8 & 97.2 \\
\hline others & 2 & 2.8 & 2.8 & 100.0 \\
\hline total & 71 & 100.0 & 100.0 & \\
\hline
\end{tabular}

\section{Conclusion}

Based on the results of this study, the high-risk groups include women; people aged 16-30 years and also those with low education levels who are more at risk. The number of religious minorities in Zahedan is very low and therefore from among 71 analyzed samples is all Muslims in terms of religion.

The percentage of women who committed suicide is more than men. Given that the suicide attempt rate among 16 to 30 year age group is higher than others as $2 / 83$ percent, so it seems that more education, social and health care should be considered at this age. Rate of attempted suicide among people with higher diploma education is less as $8 / 33$ than those with lower diploma education that make up 2/66 percent suicide.

$5 / 46 \%$ of the respondents is single and about $5 / 53 \%$ is married and no significant relationship was found between suicide and marital status. However, suicide among those who are childless with $6 / 67 \% 4 / 32$ percent is more than those with children. In other words, there is a reverse relationship between having children and attempted suicide, which represents the commitment of the people to the foundation of the family. The rate of attempted suicide among people with higher income levels and low income levels with 5.15 percent is much less than 5/84 percent among the people with a good and medium income. Further, people who are going through an economic stage to another stage have been more susceptible to this damage.

No significant relationship was found between mental disorders and suicide since 9/92 percent of people who have attempted suicide had no history of mental problem. However a variety of physical violence and violence of husband are as a total of about 2.21 percent, disputes 7.12 percent and anger as 8.0 percent which reflects some degree of mood disorders in these individuals is the sum of $7 / 34$ percent and that shows there is a significant relationship between suicide and mood disorders. There is a significant relationship between addiction, violence, conflict, critical life events and family prejudices with suicide rates as they make up a total of 6/57 percent of total cases. Self-employed people and students have had attempt suicide at 37 and 1.52 percent, respectively which is more than all other occupations with $9 / 47$ percent.

5.46 percent of suicides have been conducted between the hours of 14 to $17 \mathrm{pm} .5 .84$ percent of respondents have attempted suicide at home, 7 percent at workplace and 5.8 at the households of the acquaintances. It seems that people tend to commit suicide in their home. Therefore, taking care of people at home is very important. 9. 47percent of people take medicine to commit suicide which has the highest percentage of suicide attempts and $8 / 33$ percent of people have self-Immolation. These are two most common methods of suicide and it seems that there is a significant relationship between suicide rates and the availability of medicines and fuel. So there should be enough information about high-risk behaviors available to families and medicines and fuel should be put out of their access.

About 29.6 percent of respondents had a suicide death and about 4/70 percent of suicides have not been fatal, However, due to adverse social repercussions of disclosing that the cause of death has been due to suicide and also lack of insurance support from patients who die by suicide, the majority of patients and their families are reluctant to admit to committing suicide and in most cases suicide is detected based on the evidence and the results of physical examination. It seems that in most cases people have had suicidal were looking for a kind of attention seeking or have sought their demands. Overall, families should note that they should take the demands of the family members seriously and when the demands are not reasonable and practical, teach the family 
members the ways to deal with the problem or use the opinions of experienced advisers.

\section{Recommendations}

As mentioned before, people who think about suicide or even to act their aim is not almost always to die, rather they wish to end their feelings. In recent years many experts set their most important goal as helping suicidal person to overcome this crisis successfully and help these people using strategies such as problem-solving, acceptance and tolerance with painful thoughts and emotions. In this regard, the following measures could be taken:

- General life skills training

- Regarding skills training in school textbooks (social) students, especially at high school age

-Providing a single people the condition to get married and have a baby

-Providing the conditions of employment for the unemployed

-Taking effective ways to combat drug addiction and drying the root of this scourge on society with awareness

- Cooperation with mass media in skills training for compatibility with the environment and living conditions

-Raising the awareness of the consequences of religiously motivated belief and murder (suicide) for his family

- Controlling and monitoring suspicious behavior and speech of the children

-Raising the collective spirit of vitality and creating recreational spaces

-The need to take appropriate measures for providing and training the people who have had unsuccessful suicide.

- Creating government support centers by qualified persons for people who have decided to commit suicide or had unsuccessful suicide attempts to receive the necessary psychological and social supports.

- Establishing psychological counseling centers for all time contact and giving advice to people who were in critical condition and with a risk of suicide for them and their need for help and support.

-Criminalization of suicide and assisting in suicide consequently because the lack of punishment for abetment of suicide would have adverse effects and consequences for the individual and society. So, although the criminalization of suicide seems to be contrary to the principles of criminalization and interference with individual liberties, however, with the legislative act cannot ignore the criminal aspect of committing suicide.

- Continuation of insurance services, even after taking possession of suicide.

- The use of innovative tools and promising operations as production and frequency of brochures

\section{References}

Computer Crimes Act 2009, Penal Code of the Armed Forces offenses 2003.

Danaeefard, H., Alvani, M., \& Azar., P. (2007). Quantitative research methodology in management (2nd ed.). Safa Publication

Dehkhoda, A. (1968). dictionary. thran Certain Zyrnzrmhmd. Tehran University Press.

Durkheim., E. (2009). Suicide (Vol. 1, 1st ed.). translation by Salarzadeh Amir Naderi. Tehran. Allameh Tabatabai University Press.

Ghahari, S. (2012). Suicide prevention (Vol. 1, 1st ed.). Tehran: digital publications.

Hafeznia, M. (2008). Introduction to research methods in the humanities, SAMT, Tehran.

Hejazi, S. (2014). Understanding Medical Research Methodology (2nd ed.). Tehran: Heidari.

Hnasabzade Esfahani, M. (2010). I do not want to think about committing suicide (Vol. 1, 1st ed.). Tehran. Drop Publication.

Hojati, H. (2014). Book of nursing management. Tehran: Hakim.

Hojati, H. (2014). Research Methods and Statistics in Nursing. Tehran: Printing, community-based.

$\mathrm{http}: / / \mathrm{af} . \mathrm{samta} . \mathrm{ir}$

http://bank-maskan.ir/sistan/565/index.aspx

http://dadgostari-sb.ir/Default.aspx?tabid=1345

http://irantrack.com/Forum/thread30348.html 
http://www.qo.mefa.ir

http://www.sbportal.ir/fa/news/ /5478

http://www.sbportal.ir/fa/news//5485

http://www.tebyan.net/newindex.aspx?pid= 114898

Jafari, S. (2012). Forensics for law students (Vol. 1, 2nd ed.). Tehran. Javdane Publication, Jangal.

Khaki, G. (1997). Research method in management (1st ed.). Tehran. Islamic Azad University Publication Center.

Kuzaran, L. (2001). Life and Thought sociology major (Vol. 1, 1st ed.). Translation by Triad., M. Tehran. Publication.

Mahyar A., Nouhi S., \& Shafiee A. (2010). Suicide (Vol. 1, 2nd ed.). Tehran. Venerable Press.

Mir Mohammad Sadeghi, H. (2014). rights of first penal offenses against persons Tehran, Mizan publication, Third Edition.

Nelson, R., Alan C., \& Wilkes. A. (1996). Behavioral disorders in children (Vol. 1, 1st ed.). Translation by Monshi Tousi, M., Mashhad. Astan Quds Razavi.

Nikjou, A. R. (2014). moral sensitivity and a desire to leave the work in nurses working in teaching hospitals of Gorgan. Master's Thesis of Nursing, School of Nursing and Midwifery, Islamic Azad University, Tehran Medical Branch.

Noubakht, M. (2013). Advanced research (1st ed.). Tehran, Camille.

Palmer. S. (2011). The psychology of suicide (new strategies to reduce and prevent suicide) (Vol. 1, 1st ed.). translation by Moradian. B., Tehran. The Sound of Light.

Prohibition of suicide, its causes and consequences, Mobaleghan, September and October 2004, No. 59 Page 55.

Rafipour, F. (2009). Anomie or social disorganization (Vol. 1, 1st ed.). Tehran. Soroush Publications.

Salimi, A., \& Davari. M. (2001). Studies in social pathology (Vol. 1, 1st ed.). Tehran Sound of Light Publication.

Sarmad, Z., Bazargan., A., \& Hajari., E. (2009). Research Methods in the Behavioral Sciences (17th ed.).

Schneiderman, E. S. (2013). Psychology of suicide, suicidal mind (Vol. 1, 1st ed.). Translation by M. Firoz Bakht. Tehran. Psychology and art publications.

Skaran, U. (2012). Research Methods in Management (10th ed.). Translation by Saeb M., and Shirazi, M. Tehran. presidential administration Center of Management Training.

Sotoude, H. (2010). syb Social Sciences (Sociology of social deviations) (Vol. 1, 1st ed.). Tehran . Publication Sound of Light.

Stengel, E., (1995). Suicide and attempted suicide (Vol. 1, 1st ed.). translation Sahebjam, H., Tehran. Ashraf Publications.

Tabatabaei, S. (2005). Detection and prevention of youth suicide. Monthly social, cultural, educational, correctional, 41, senior, p. 21. 46.

Taylor, S. T. (1990). Sociology suicide (Vol. 1, 1st ed.). Translation by Rabbani, R., Ansari, I., and Karshenas., M. Tehran . Sound of Light Publication.

The Holy Quran.

Walidi, M. (2001). Special criminal law; crimes against persons (6th ed.). Tehran: Amir Kabir, p. 141.

\section{Copyrights}

Copyright for this article is retained by the author(s), with first publication rights granted to the journal.

This is an open-access article distributed under the terms and conditions of the Creative Commons Attribution license (http://creativecommons.org/licenses/by/4.0/). 